\title{
FLT3 Tyrosine Kinase Domain Mutation Negative
}

National Cancer Institute

\section{Source}

National Cancer Institute. FLT3 Tyrosine Kinase Domain Mutation Negative. NCI

Thesaurus. Code C156059.

An indication that FLT3 gene mutations in the region encoding the tyrosine kinase domain have not been detected in a sample. 